Avalaible online: https://ejournal.iai-tribakti.ac.id/index.php/pgmi

Article doi: https://doi.org/10.33367/jiee.v3i1.1537

Submission: 2021-1-24 Review: 2021-1-30 Accepted: 2021-1-30

\title{
Analisis Keterampilan Berpidato Siswa Kelas IV Sekolah Dasar Negeri 188 Pekanbaru
}

\section{Analysis Of Speaking Skills Class IV State 188 Pekanbaru Students}

\author{
Iskandar Zulkarnain Gunawan', Otang Kurniaman², Zufriady ${ }^{\mathbf{3}}$ \\ ${ }^{1}$ Universitas Riau, ${ }^{2}$ Universitas Riau, ${ }^{3}$ Universitas Riau \\ 1iskandar.zulkarnain3824@student.unri.ac.id; ${ }^{2}$ otang.kurniaman@lecture.unri.ac.id; \\ 3zufriady@lecturer.unri.ac.id
}

\begin{abstract}
The background of this research is that speaking skills are one aspect of language skills that students must master, in addition to the three other skills, namely reading, listening and writing. Learning to Speak in Elementary School which is given through Indonesian Language subjects. Although learning to Speak has been recognized as an important part of learning Indonesian in elementary schools, in fact speaking learning has received less attention from teachers and students. One of the speaking skills that needs to be asked is the skill in making a speech. For that reason, the researcher conducted a research that aimed to describe the skills of students in grade IV at State of Elementary School 188 Pekanbaru. This research is a descriptive quantitative research conducted at State of Elementary School 188 Pekanbaru with 80 students as research subjects. The instrument used to collect data was the student sample sheet test which contains indicators in making speeches. The results showed that students who got the very skilled category were $17.05 \%$. In the skilled category as much as $31.25 \%$. In the sufficiently skilled category as much as $50 \%$. The students' skills are in the skilled category with an average score of 78.05.
\end{abstract}

Key Word: Oratory skills, Indonesian Language, Speak

\begin{abstract}
Abstrak
Latar belakang penelitian ini adalah Keterampilan berbicara merupakan salah satu aspek keterampilan berbahasa yang harus dikuasai siswa, selain ketiga keterampilan lain yaitu membaca, menyimak dan menulis. Pembelajaran berbicara di Sekolah Dasar diberikan melalui mata pelajaran Bahasa Indonesia. Meskipun pembelajaran berbicara telah disadari merupakan bagian penting dalam pembelajaran Bahasa Indonesia di Sekolah Dasar, namun pada kenyataannya pembelajaran berbicara kurang mendapat perhatian dari guru maupun siswa. Salah satu contoh keterampilan berbicara yang perlu di perhatikan adalah keterampilan dalam berpidato untuk itu peneliti melakukan penelitian yang bertujuan untuk mengetahui serta mendeskripsikan keterampilan siswa dalam berpidato di kelas IV di Sekolah
\end{abstract}


Analisis Keterampilan Berpidato Siswa Kelas IV Sekolah Dasar Negeri 188 Pekanbaru

Oleh: Iskandar Zulkarnain Gunawan, Otang Kurniaman, dan Zufriady

Dasar Negeri 188 Pekanbaru. Penelitian ini merupakan penelitian kuantitatif deskriptif yang dilakukan di Sekolah Dasar Negeri 188 Pekanbaru dengan subjek penelitian sebanyak 80 siswa. Instrumen yang digunakan untuk mengumpulkan data adalah tes lembar penilaian siswa yang berisikan indikator dalam berpidato. Hasil penelitian ini menunjukan bahwa siswa yang mendapatkan kategori sangat terampil sebanyak 17.05\%. Pada kategor terampil sebanyak 31,25\%. Pada kategori cukup terampil sebanyak 50\%. Umumnya keterampilan berpidato siswa berada pada kategori terampil dengan nilai rata-rata 78,05.

Kata Kunci: Keterampilan Berpidato, Bahasa Indonesia, Berbicara

\section{Pendahuluan}

Keterampilan adalah suatu kemampuan dan kapasitas yang diperoleh melalui usaha yang disengaja, sistematis, dan berkelanjutan untuk secara lancar dan adaptif melaksanakan aktivitas-aktivitas yang kompleks atau fungsi pekerjaan yang melibatkan ideide (keterampilan kognitif), hal-hal (keterampilan teknikal), dan orangorang (keterampilan interpersonal) ${ }^{1}$. Keterampilan dapat dilatih sehingga mampu melakukan sesuatu, tanpa adanya latihan dan proses pengasahan akal, fikiran tersebut tidak akan bisa menghasilkan sebuah keterampilan karena keterampilan bukanlah bakat yang bisa saja didapat tanpa proses belajar yang intensif dan merupakan kelebihan yang sudah diberikan sejak lahir ${ }^{2}$. Berpidato merupakan penampilan diri seseorang di hadapan pendengar untuk menyampaikan isi hati atau buah pikiran dengan rangkaian kata-kata dengan harapan agar pendengar tergugah hati nuraninya dan tergerak pikirannya ${ }^{3}$. Pidato

\footnotetext{
${ }^{1}$ Hermawan, MENYIMAK: Keterampilan

Berkomunikasi yang Terabaikan.

2 Tarigan, Menyimak sebagai suatu keterampilan berbahasa.

${ }^{3}$ Saksomo, Berbicara Monologis (Wicara Individual).

umumnya ditujukan kepada orang atau sekumpulan orang untuk menyatakan selamat, menyambut kedatangan tamu, memperingati hari-hari besar dan lain sebagainya.

Undang-undang Republik Indonesia Nomor 20 Tahun 2003 tentang system pendidikan Nasional (Sisdiknas) telah merumuskan fungsi dan tujuan pendidikan nasional. Dalam pasal 3 UU yang isinya, "Pendidikan Nasional berfungsi mengembangkan dan membentuk watak serta peradaban bangsa yang bermartabat dalam rangka mencerdaskan kehidupan bangsa, bertujuan untuk berkembangnya potensi setiap peserta didik agar menjadi manusia yang beriman dan bertaqwa kepada Tuhan YME. ${ }^{4}$

Keterampilan berpidato merupakan salah satu aspek keterampilan berbahasa yang harus dikuasai siswa, selain ketiga keterampilan lain yaitu membaca, menyimak dan berbicara. Pembelajaran beridato di SD diberikan melalui mata pelajaran Bahasa Indonesia. meskipun pembelajaran berbicara telah disadari merupakan bagian

\footnotetext{
${ }^{4}$ Kementerian Pendidikan Nasional, 2010. Pengembangan Pendidikan Budaya dan karakter bangsa : Pedoman Sekolah, Jakarta : badan penelitian dan Pengembangan Pusat kurikulum.
} Volume 3, Nomor 1, Maret 2021 
penting dalam pembelajaran Bahasa Indonesia di SD, namun pada kenyataannya pembelajaran berpidato mendapat kurang perhatian dari guru maupun siswa. Pembelajaran berbicara atau berpidato kurang ditangani secara sungguh-sungguh, sehingga keterampilan berpidato yang dimiliki siswa kurang memadai. rendahnya keterampilan berpidato karangan disebabkan oleh kenyataan pembelajaran berpidato yang di anak tirikan. Pada umumnya guru lebih memfokuskan kegiatan pembelajaran hanya pada materi teoritik yang ditekankan pada keberhasilan siswa dalam Ujian Nasional. Keterampilan berpidato sangat penting untuk dikuasai peserta didik. Keterampilan berpidato banyak memberikan manfaat dalam kehidupan yang serba maju sekarang ini. berpidato merupakan suatu kegiatan yang penting untuk dapat menuangkan isi pikiran,gagasan atau pendapat, ide maupun perasaan seseorang.

Keterampilan berpidato harus diajarkan dalam bentuk aktivitas pembelajaran yang bermakna dan menarik bagi siswa. Selain itu, juga dapat dioptimalkan dengan peran guru yang mampu menciptakan suatu lingkungan belajar yang kondusif. Guru harus bisa memahami kesulitan yang dihadapi siswa ketika berpidato. guru yang memahami kesulitan siswa dalam berpidato akan memberikan pengertian bahwa berpidato tidak harus sekali penampilan harus sempurna. Kekurangan maupun kesalahan adalah sebuah proses belajar. Pembelajaran berpidato menuntut kerja keras guru untuk membuat pembelajaran yang menyenangkan sehingga siswa tidak merasa dipaksa untuk tampil berpidato, tetapi sebaliknya siswa merasa senang hatinya untuk berbicara sebagai media menuangkan ekspresinya.

Terdapat beberapa usaha yang harus dilakukan, antara lain, Pada hal ini persiapan pidato berupa pembagian dan penyusunan pikiran serta pendapat sesuai dengan permasalahan yang akan dibahas metode Penyampaian Pidato, Untuk menarik pendengar pilih metode semenarik mungkin untuk menyampaikan pemikiran anda dengan dikemas semenarik mungkin agar mudah tersampaikan oleh pendenga perencanaan Pidato, Pada tahap terakhir kita wajib meneliti masalah yang akan disampaikan. Susun pidato dan latihan oral agar pidato yang akan kita sampaikan agar jauh lebih matang. Syarat Pidato yang Baik Pidato yang baik tidak lepas dari berbagai syarat yang harus dicapai oleh setiap siswa yang melakukan pidato. Berpidato memiliki tujuan untuk mengajak orang lain sesuai dengan gagasan yang kita miliki. Tetapi, tidak semua orang mampu menyampaikannya dengan runtut dan baik. Syarat pidato yang baik berisi tentang adanya pokok masalah atau isi yang akan diuraikan. Sudah seharusnya kita menguasai dan cakap dalam menyampaikan permasalahan yang diangkat.

Berdasarkan penjelasan tersebut, peneliti melakukan penelitian dengan judul " ini karena peneliti ingin mengetahui sejauh mana keterampilan siswa kelas IV SD Negeri 188 Pekanbaru dalam menampilakan sebuah pidato. Peneliti juga ingin menge- 
tahui sejauh mana penguasaan penggunaan bahasa dalam menampilkan sebuah pidato. Karena keterampilan berbicara siswa harus diajarkan sejak dini dimulai dari jenjang sekolah dasar sesui dengan peraturan pemerintah dengan tujuan agar terebentuk keterampilan berbicara dan dapat menerapkan dalam kehidupan seharihari. Keterampilan berpidato siswa dapat diukur melalui indikatorindikator keterampilan berpidato itu sendiri.

\section{Metode}

Penelitian ini merupakan penelitian kuantitatif deskriptif. Penelitian ini dilakukan di SD Negeri 188 Pekanbaru. Subjek penelitian ini adalah siswa kelas IV dengan jumlah 80 siswa. Penelitian ini dilakukan pada tanggal 20 Maret 2020 sampai dengan 29 April 2020.

Instrumen penelitian ini adalah lembar penilaian siswa sebanyak 5 butir indikator terhadap keterampilan berpidato. Teknik pengumpulan data yang digunakan dalam penelitian ini adalah teknik tes lisan. Teknik analisis yang digunakan adalah analisis deskriptif. Data tersebut dikelompokkan berdasarkan kategori-kategori berikut:

Tabel 1. Kriteria dan Kategori Keterampilan Siswa dalam Berpi-dato

\begin{tabular}{|c|c|l|}
\hline $\begin{array}{c}\text { Interval } \\
\text { Presentase }\end{array}$ & $\begin{array}{c}\text { Nilai Ukuran } \\
\text { Skala }\end{array}$ & Keterangan \\
\hline $85-100$ & $\mathrm{~A}$ & $\begin{array}{l}\text { Sangat } \\
\text { terampil }\end{array}$ \\
\hline $70-84$ & $\mathrm{~B}$ & Terampil \\
\hline $50-69$ & $\mathrm{C}$ & $\begin{array}{l}\text { Cukup } \\
\text { terampil }\end{array}$ \\
\hline $0-49$ & $\mathrm{D}$ & $\begin{array}{l}\text { Kurang } \\
\text { terampil }\end{array}$ \\
\hline
\end{tabular}

\footnotetext{
${ }^{5}$ Nurgiyantoro, Penilaian Pembelajaran Bahasa Indonesia Berbasis Kompetensi. 4
}

Setelah masing-masing siswa dikategorikan menurut keterampilan dalam berpidato, kemudian peneliti membuat tabel distribusi frekuensi agar data yang telah dikumpulkan dalam jumlah banyak dapat disajikan dalam bentuk yang jelas dan baik. Selain itu juga untuk menyederhanakan bentuk dan jumlah data sehingga ketika data disajikan akan lebih mudah dipahami.

\section{Temuan dan Pembahasan Temuan penelitian}

Hasil penelitian ini mendeskripsikan atau menganalisis data keterampilan berpidato siswa dengan pembahasan data tentang ketepatan ucapan, intonasi, pemilihan kata atau diksi, gaya atau ekspresi, dan penguasaan topik. Adapun data keterampilan siswa dalam berpidato sebagai berikut:

\section{Data Ketepan Ucapan}

Keterampilan siswa dalam berpidato berdasarkan indikator ketepatan ucapan dikelas IV Sekolah Dasar Negeri 188 Pekanbaru dapat dilihat pada gambar 1 berikut.

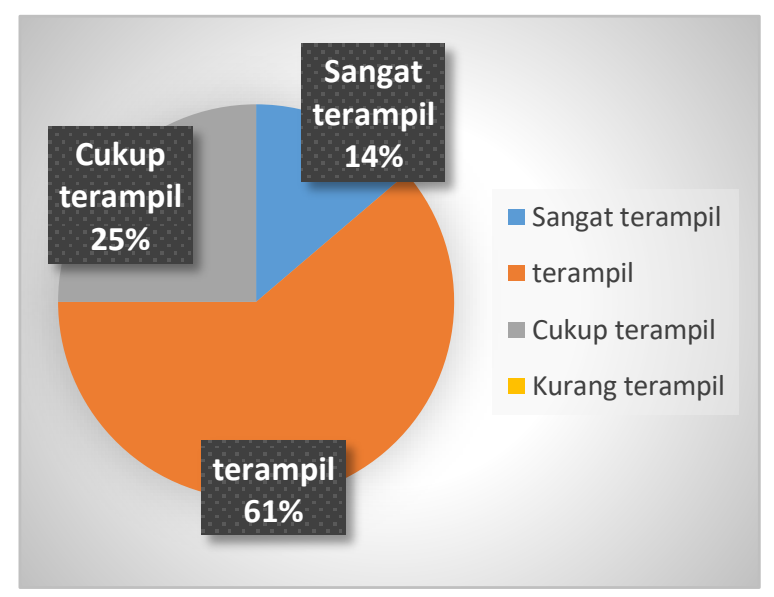

Gambar 1. Keterampilan Berpidato Siswa Kelas IV Berdasarkan Indikator Ketepatan Ucapan

Berdasarkan gambar di atas dapat disimpulkan perolahan nilai perindikator siswa dalam berpidato, siswa el Bidayah: Journal of Islamic Elementary Education Volume 3, Nomor 1, Maret 2021 
yang memperoleh kategori sangat terampil berjumlah 11 siswa, siswa yang memperoleh kategori terampil berjumlah 49 siswa, sedangkan siswa yang memperoleh kategori cukup terampil berjumlah 20 siswa. jika dipersentasekan setiap kategori maka diperoleh nilai, siswa yang memeproleh kategori sangat terampil sebanyak $13,75 \%$, siswa yang memperoleh terampil sebanyak $61,25 \%$, dan siswa yang memperoleh kategori cukup terampil sebanyak 25\%. Jika dijumlahkan keseluruhan nilai maka berjumah 310 dan jika nilai tersebut di rata-ratakan memperoleh nilai 77,5 . Jadi dapat disimpulakan pada keterampilan siswa dalam berpidato pada indikator ketepatan lafal/ucapan dikategorikan cukup terampil hal ini dilihat dari jumlah rata-rata dan karena siswa yang memperoleh nilai tinggi lebih dominan.

\section{Data Intonasi}

Keterampilan siswa dalam berpidato pada kelas IV SD Negeri 188 Pekanbaru berdasarkan indikator berintonasi dalam kita liat pada gambar 2 berikut

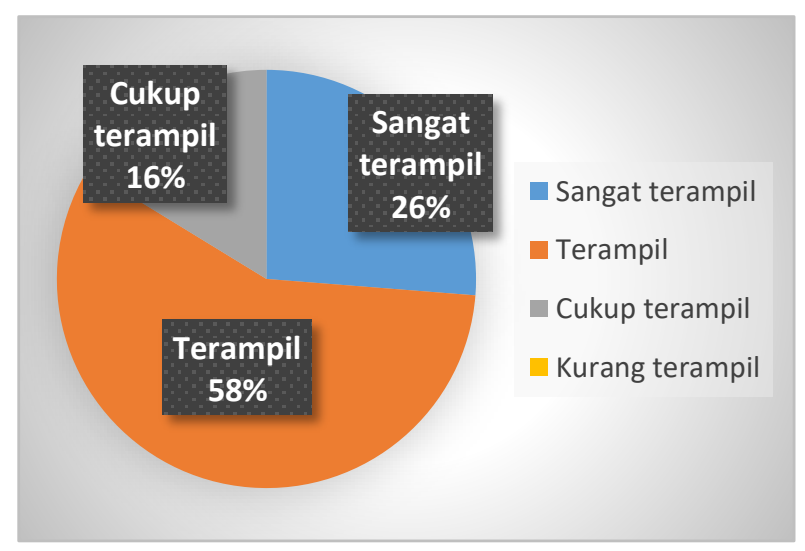

Gambar 2. Keterampilan Berpidato Siswa Kelas IV Berdasarkan Indikator Intonasi
Berdasarkan gambar diatas dapat disim-pulkan perolahan nilai perindikator siswa dalam berpidato siswa yang memperoleh kategori sangat terampil berjumlah 13 siswa, siswa yang memperoleh kategori terampil berjumlah 46 siswa, dan siswa yang memperoleh kategori cukup terampil berjumlah 21 siswa. jika dipersentasekan setiap nilai maka diperoleh nilai, siswa yang memeproleh kategori sangat terampil sebanyak 16,25\%, siswa yang memperoleh kategori sebanyak 57,5\%, dan siswa yang memperoleh kategori cukup terampil sebanyak 26,25\%. Jika dijumlahkan keseluruhan nilai maka berjumah 328 dan jika nilai tersebut di rata ratakan memperoleh nilai 82. Jadi dapat disimpulakan pada keterampilan siswa dalam berpidato pada indikator berintonasi dikategorikan sangat terampil hal ini karena siswa yang memperoleh nilai tinggi lebih dominan.

\section{Data Pilihan Kata/Diksi}

Keterampilan siswa dalam berpidato pada kelas IV SD Negeri 188 Pekanbaru berdasarkan indikator pemilihan kata /diksi dapat kita liat pada gambar 3 berikut:

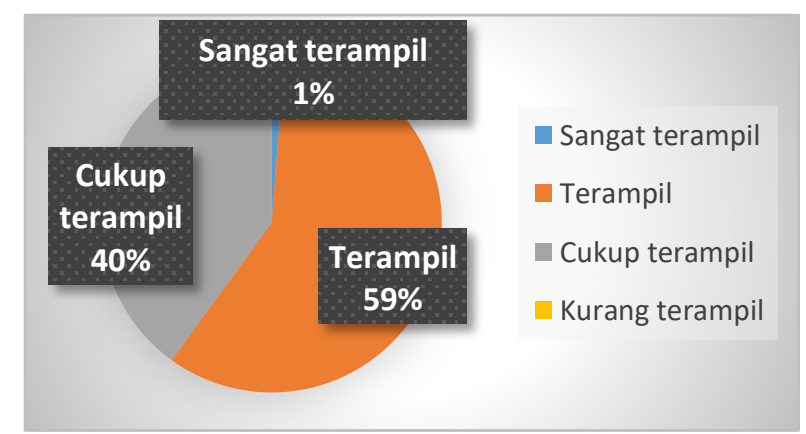

Gambar 3. Keterampilan Berpidato Siswa Kelas IV Berdasarkan Indikator Pilihan Kata/diksi 
Berdasarkan gambar diatas dapat disimpulkan perolahan nilai perindikator siswa dalam berpidato siswa yang memperoleh kategori sangat terampil berjumlah 1 siswa, siswa yang memperoleh kategori terampil berjumlah 47 siswa, dan siswa yang memperoleh kategori cukup terampil berjumlah 32 siswa. jika dipersentasekan setiap nilai maka diperoleh nilai, siswa yang memeperoleh kategori cukup terampil sebanyak $40 \%$, siswa yang memperoleh kategori terampil sebanyak 58,75\%, dan siswa yang memperoleh sangat terampil sebanyak 1,25\%. Jika dijumlahkan keseluruhan skor maka berjumah 289 dan jika skor tersebut di rata ratakan memperoleh nilai 72,25 . Jadi dapat disimpulakan pada keteram-pilan siswa dalam berpidato pada indikator pemilihan kata/diksi dikate-gorikan cukup terampil hal ini karena siswa yang memperoleh nilai tinggi lebih dominan.

\section{Data Gaya/ekspresi}

Keterampilan siswa dalam berpidato pada kelas IV SD Negeri 188 Pekanbaru berdasarkan indikator indikator gaya/ ekspresi dapat kita liat pada gambar berikut:

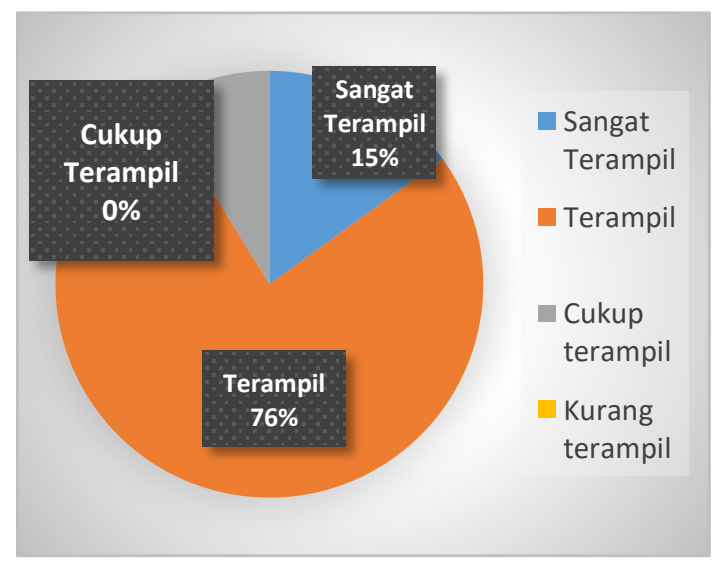

Gambar 4. Keterampilan Berpidato Siswa Kelas IV Berdasarkan Indikator Gaya/ekspresi

6
Berdasarkan gambar diatas dapat disim-pulkan perolahan nilai perindikator siswa dalam berpidato, siswa yang memperoleh kategori cukup terampil berjumlah 7 siswa, siswa yang memperoleh kategori terampil berjumlah 61 siswa, siswa yang memperoleh kategori sangat sangat terampil berjumlah 12 siswa. jika dipersentasekan setiap nilai maka diperoleh nilai, siswa yang memperoleh kategori cukup terampil sebanyak $8,75 \%$, siswa yang memperoleh kategori terampil sebanyak $76,25 \%$, dan siswa yang memperoh kategori sangat terampil sebanyak 15\%. Jika dijumlahkan keseluruhan nilai maka berjumah 325 dan jika nilai tersebut di rata ratakan memperoleh nilai 81,25. Jadi dapat disimpulakan pada keterampilan siswa dalam berpidato pada indikator pemilihan kata/diksi dikategorikan terampil hal ini karena siswa yang memperoleh nilai tinggi lebih dominan.

\section{Data Penguasaan Topik Pidato}

Keterampilan siswa dalam berpidato pada kelas IV SD Negeri 188 Pekanbaru berdasarkan indikator penguasaan topik dapat kita liat pada gambar berikut:

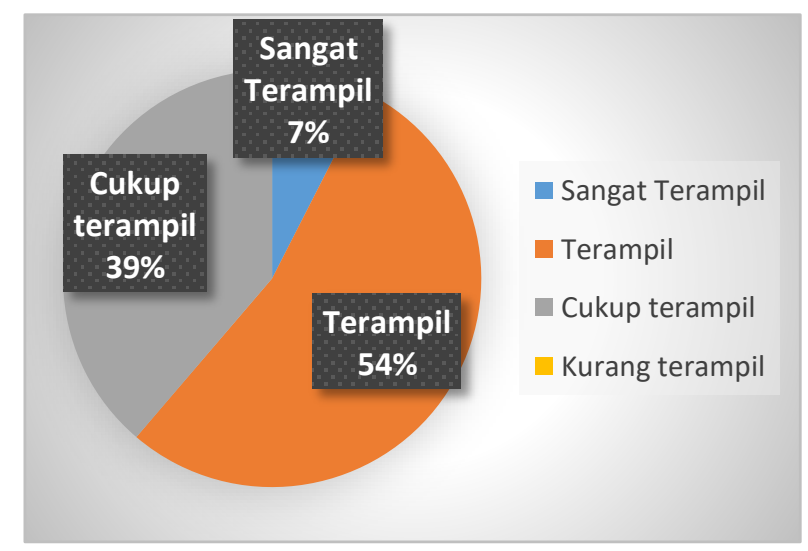

Gambar 5. Keterampilan Berpidato Siswa Kelas IV Berdasarkan Indikator Penguasaan Topik

el Bidayah: Journal of Islamic Elementary Education Volume 3, Nomor 1, Maret 2021 
Berdasarkan gambar diatas dapat disimpulkan perolahan nilai perindikator siswa dalam berpidato, siswa yang memperoleh kategori sangat terampil berjumlah 6 siswa, siswa yang memperoleh kategori terampil berjumlah 43 siswa, siswa yang memperoleh kategori cukup terampil berjumlah 31 siswa. jika dipersentasekan setiap nilai maka diperoleh nilai, siswa yang memperoleh kategori sangat terampil sebanyak $7,5 \%$, siswa yang memperoleh kategori terampil sebanyak $53,75 \%$, dan siswa yang memperoleh kategori cukup terampil sebanyak 38,75\%. Jika dijumlahkan keseluruhan nilai maka berjumah 295 dan jika nilai tersebut di rata ratakan memperoleh nilai 73,75 . Jadi dapat disimpulakan pada keterampilan siswa dalam berpidato pada indikator penguasaan materi/topik dikategorikan cukup terampil hal ini karena siswa yang memperoleh nilai tinggi lebih dominan.

\section{Data Rekapitalasi Hasil Analisis Keterampilan Berpi- dato Siswa Kelas IV SD Negeri 188 Pekanbaru}

Berdasarkan penelitian yang telah dilakukan didapatkan hasil penelitian mengenai keterampilan berpidato di Sekolah Dasar Negeri 188 Pekanbaru, dapat diketahui dari nilai keseluruhan indikator memperoleh nilai rata rata sebesar 78,05. Selanjutnya penulis akan mendeskripsikan data hasil penelitian mengenai indikator keterampilan berpidato siswa kelas IV Sekolah Dasar Negeri 188 Pekanbaru.

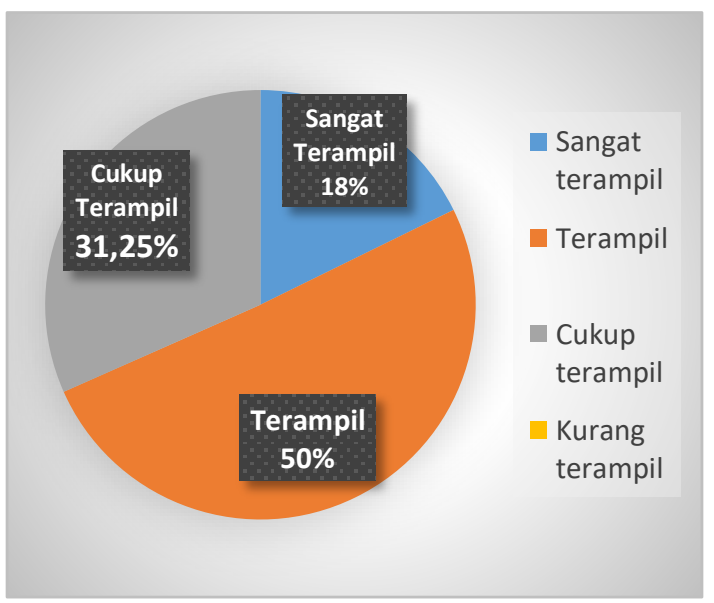

Gambar 6. Keterampilan Berpidato Siswa Kelas IV Berdasarkan Keseluruhan Indikator

Berdasarkan gambar diatas dapat disimpulkan perolahan nilai perindikator siswa dalam berpidato, siswa yang memperoleh kategori sangat terampil berjumlah 14 siswa, siswa yang memperoleh kategori terampil berjumlah 40 siswa, sedangkan siswa yang memperoleh kategori cukup terampil berjumlah 25 siswa. jika dipersentasekan setiap kategori maka diperoleh nilai, siswa yang memeproleh kategori sangat terampil sebanyak $17,5 \%$, siswa yang memperoleh terampil sebanyak $40 \%$, dan siswa yang memperoleh kategori cukup terampil sebanyak 31,25\%. Jika dijumlahkan keseluruhan nilai maka berjumah 1559 dan jika nilai tersebut di rata-ratakan memperoleh nilai 78,05 . Jadi dapat disimpulakan pada keterampilan siswa dalam berpidato pada indikator ketepatan lafal/ucapan dikategorikan terampil hal ini dilihat dari jumlah ratarata dan karena siswa yang memperoleh nilai tinggi lebih dominan. 


\section{Pembahasan}

Pembahasan hasil penelitian merupakan pemikiran peneliti yang terkait dengan apa yang telah peneliti temukan, lalu dipaparkan dan dianalisis di bab sebelumnya. Uraian mengenai pemikiran ini di kaitkan dengan hasil kajian teori dan hasil-hasil penelitian lain yang relevan guna menjawab pertanyaan penelitiannya. Berdasarkan analisis dari hasil lembar penilaian mengenai Keterampilan Berpidato Siswa Kelas IV SD Negeri 188 Pekanbaru dapat dapat dilihat dari 5 indikator.

Ketepatan ucapan merupakan pengucapan bunyi-bunyi bahasa secara tepat, mengucapkan bunyi bahasa yang kurang tepat, dapat mengalihkan perhatian pendengar6. Pengucapan bunyi bahasa yang kurang tepat atau cacat tersebut juga menimbulkan kebosanan, kurang menyenangkan, atau kurang menarik ${ }^{7}$. Sebuah penampilan pidato dikatakan sudah sangat baik apabila dalam pelaksanaanya sudah tidak tidak ditemukan kesalahan dalam ucapaan serta pelafalan dengan kata lain pengucapan kata-kata dalam berpidato sudah tepat. Berdasarkan hasil pengolahan data indikator ketepatan ucapan pada tabel dan diagram memperoleh nilai sebesar 77,5 dengan terampil. Hal ini menunjukkan keterampilan siswa dalam berpidato dikelas IV SD Negeri 188 Pekanbaru masih tergolong baik, hal tersebut

\footnotetext{
${ }^{6}$ Karim dan Abdullah, "Meningkatkan Kemampuan Berbicara pada Siswa Kelas IV SD Negeri 38 Kota Ternate Melalui Model Pembelajaran Role Play."

${ }^{7}$ Arsjad, Pembinaan kemampuan berbicara bahasa Indonesia.

dibuktikan dengan hasil penelitian dan pengolahan data yang telah dilaksanakan sebelumnya.

Penggunaan intonasi yang tepat, bervariasi, dan tidak monoton menjadikan pendengar akan tertarik. Hal tersebut belum sepenuhnya dilakukan oleh siswa-siswa kelas IV SD Negeri 188 Pekanbaru, masih ada siswa yang menggunakan intonasi secara mendatar, hal ini membuat penampilan pidato menjadi hambar, dan pendengarpun merasa bosan. Sebuah penampilan pidato sudah dikatakan sangat baik saat berintonasi apabila dalam penyampaian dengan intonasi yaitu, penempatan tekanan, sendi nada, dan durasi yang sesuai dan tetap. Berdasarkan hasil pengolahan data indikator berintonasi bahwa keterampilan siswa dalam berpidato diperoleh nilai sebesar 82 dengan kategori sanagt terampil. Hal ini menunjukkan bahwa keterampilan siswa pada saat membawakan pidato dengan intonasi bisa dikatakan sangat memuaskan. meskipun demikian, memperoleh nilai yang tinggi tidak menutup kemungkina adanya nilai yang rendah, hal ini ditandai dengan adanya siswa yang kurang maksimal pada saat membawakan pidato dengan intonasi yang datar dan terkesan monoton. Sehingga guru kedepannya bisa lebih memaksimalkan agar ditingkatkan lagi. Aspek Pilihan Kata Penilaian pada aspek pilihan kata meliputi ketepatan penggunaan kata, kata-kata yang digunakan mendukung atau tidak dengan gagasan utama dan juga pemilihan kata yang sama sekali tidak terpengaruh unsur kedaerahan. Variasi Volume 3, Nomor 1, Maret 2021 
pemakaian bahasa dipengaruhi oleh situasi pembicara Dari penilaian pratindakan, Nilai rata-rata siswa pada aspek ini mencapai 72,25 , skor ratarata ini termasuk dalam katagori sedang. Ketika praktik berpidato, masih ditemukan siswa menggunakan katakata yang kurang mendukung gagasan, serta masih terpengaruh dengan kosakata bahasa ibu. Dengan demikian, aspek pilihan kata perlu ditingkatkan lagi.

Gaya yang dimaksudkan adalah pembawaan yang ditampilkan saat berpidato, gaya/ekspresi dapat meningkatkan kesan dan pesan yang akan disampikan dalam beripidato. Sesuai dengan apa yang ada dalam naskah pidato, seperti orator tertawa, gerakan anggota tubuh, dan dengan irama pidato. Gunakanlah gestur yang sesuai yang akan memberikan pesan kepada pendengar, baik gerakan tangan, kepala, dan arah badan kita. Berdasarkan hasil pengolahan data pada indikator gaya/ekspresi bahwa keterampilan siswa dalam berpidato diperoleh nilai sebesar 81,25 dengan kategori sangat terampil, hal ini menunjukkan keterampilan siswa dalam berpidato bisa dikatakan siswa menguasai indikator ini sehigga tidak ditemukan kesulitan yang berarti dalam penampilan pidato. Namun masih ada ditemukan siswa yang belum maksimal pada saat penampilan pidato, hal ini dipengaruhi oleh ketidak percayaan diri pada siswa sehingga pada saat berpidato terkesan monoton dan kaku, hal ini bisa menjadi acuan dan motivasi guru untuk bisa membangakitkan kepercayaan diri siswa akan kedepannya tidak terjadi kejadian yang sama.

Penguasaan topik dalam berpidato sangat berperan penting perlu ada persiapan, tujuannya agar topik yang dipiih betul-betul di kuasai dan pahami. karena penguasaan topik yang baik akan menumbuhkan kepercayaan diri dan kelancaran dalam berpidato $^{8}$. Jadi penguasaan topik sangat penting bahkan merupakan faktor utama dalam sebuah pidato. Berdasarkan pengolahan data yang telah dilakukan pada indikator penguasaan topik/materi mendapatkan nilai sebesar 73,75 dan tergolong kedalam kategori terampil. Hal ini menunjukkan keterampilan siswa dalam berpidato pada indikator penguasaan topik bisa dikatakan sudah menguasai. Namun, masih banyak ditemukan juga siswa yang belum menerapkan sehingga penampilan siswa dalam berpidato masih kurang maksimal.

\section{Kesimpulan}

Berdasarkan analisis dan pembahasan yang telah diuraikan mengenai analisis keterampilan berpidato siswa kelas IV SD Negeri 188 Pekanbaru Berdasarkan hasil tes apabila dilihat dari nilai per indikator maka nilai keterampilan Dari hasil penelitian diatas peneliti dapat mengambil kesimpulan bahwasannya tingkat keterampilan siswa kelas IV SD Negeri 188 Pekanbaru tergolong kedalam kategori terampil, hal ini dapat dilihat dari hasil analisis keterampilan

${ }^{8}$ Hartono, DIKTAT KULIAH: Berbicara Retorik. 
Analisis Keterampilan Berpidato Siswa Kelas IV Sekolah Dasar Negeri 188 Pekanbaru

Oleh: Iskandar Zulkarnain Gunawan, Otang Kurniaman, dan Zufriady

siswa yang telah peniliti lakukan. Hal ini

juga dilihat dari hasil penilaian perindikator yang telah di analisis sedemikian rupa sehinga menghasilkan keterampilan siswa dalam berpidato. Pada penilian perindikator ini peneliti medapatkan hasil bahwa siswa lebih dominan menguasai keterampilan pada indikator gaya/ekpresi dan indikotar intonasi, hal ini dapat dilihat dari hasil perolehan skor siswa dalam lembar penilaian siswa yang menunjukkan hasil yang sangat memuaskan. Sedangkan pada indikator lainnya masih banyak ditemui siswa yang kurang menguasai sehingga penampilan siswa dalam berpidato tidak maksimal.

Bedasarkan simpulan hasil penelitian yang telah dipaparkan di atas, maka peneliti ingin memberikan saran, diharapkan guru lebih mengembangkan kreatifitas dalam proses pembelajaran sebagai rangsangan untuk memberikan dorongan siswa dalam meningkatkan keterampilan berpidato siswa. Bagi peneliti berikutnya sebagai referensi dalam menyelesaikan penelitian yang serupa dengan keterampilan siswa dalam berpidato. diharapkan melihat dan mengembangkan wawasan anak tentang indikator yang belum siswa kuasai agar siswa lebih terampil dalam berpidato.

\section{Daftar Pustaka}

Arsjad, Maidar G. Pembinaan kemampuan berbicara bahasa Indonesia. Jakarta: Erlangga, 1991.

Hartono. DIKTAT KULIAH: Berbicara Retorik. Yogyakarta: FAKULTAS BAHASA DAN SENI
UNIVERSITAS NEGERI YOGYAKARTA, t.t.

Hermawan, Herry. MENYIMAK:

Keterampilan Berkomunikasi yang Terabaikan. Yogyakarta: Graha Ilmu, 2012.

Karim, Kodrat Hi., dan Suhardi Abdullah. "Meningkatkan Kemampuan Berbicara pada Siswa Kelas IV SD Negeri 38 Kota Ternate Melalui Model Pembelajaran Role Play." EDUKASI - Jurnal Pendidikan 17 no.2 (t.t.): 101-12.

Kementerian Pendidikan Nasional, 2010. Pengembangan Pendidikan Budaya dan karakter bangsa : Pedoman Sekolah, Jakarta : badan penelitian dan Pengembangan Pusat kurikulum., t.t.

Nurgiyantoro, Burhan. Penilaian Pembelajaran Bahasa Indonesia Berbasis Kompetensi. Yogyakarta: BPFE-Yogyakarta, 2014.

Saksomo, Dwi. Berbicara Monologis (Wicara Individual). Malang: Universitas Negeri Malang, 2009.

Tarigan, Henry Guntur. Menyimak sebagai suatu keterampilan berbahasa. Bandung: Angkasa, 2008. 